\title{
Domesticating Urban Theory? US Concepts, British Cities and the Limits of Cross-national Applications
}

\author{
Andrew M. Wood \\ [Paper first received, May 2003; in final form, January 2004]
}

\begin{abstract}
Summary. The efficacy of the urban regime and growth machine concepts beyond the US remains a matter of considerable debate. Some argue that these frameworks retain considerable value so long as they are 'properly' applied and that recent concerns about the limits to these frameworks result from no more than their 'misapplication'. I critically examine this argument through a review of recent work on the mobilisation of business interests in British cities. The central claim is that, even when focused on the 'right' issues and questions, US frameworks quickly exhaust their explanatory capacity. In the context of a widening diversity of alternative approaches, I suggest that it is time to move squarely beyond growth coalition and regime accounts. The paper makes a number of suggestions for ways in which this new phase of theory building might proceed.
\end{abstract}

\section{Introduction}

By the early 1990s, the growth coalition and urban regime concepts were firmly established as the dominant frameworks for studying US urban politics. With the domestic market for urban theory seemingly secure, these frameworks were increasingly exported to examine a variety of non-US contexts. Yet despite its early promise, this process appears to have rather quickly run its course in the face of critical accounts that point to the context-specific nature of the original formulations (Ward, 1996; Peck and Tickell, 1995; Jessop et al., 1999; Davies, 2003). The primary objective of this paper is to review British applications of US theory in order to determine its efficacy in the British context. I conclude that the value of established US theories is decidedly limited. A secondary objective is to begin to consider ways in which the study of urban politics and governance might develop in a post-urban regime/ growth machine context. Here I argue that alternative accounts, focused on the restructuring of the state, fail to address a number of the central concerns of the growth machine and regime literature - not least, the political mobilisation of business interests. In conclusion, I make the case for greater use of the strategic-relational approach of Jessop and Hay as a means of seeking to address this problem.

Clearly, not all commentators ascribe to 
the view that transnational applications of US frameworks are of limited value. Harding et al. (2000, p. 987) write, in this journal, that cross-national empirical work deploying these concepts has "enriched the literature on urban politics". Mossberger and Stoker (2001, p. 830) claim likewise that the use of the urban regime concept beyond North America has "facilitated the development of a valuable and plausible political economy perspective". Nevertheless, both of these accounts readily acknowledge the limited nature of the returns from cross-national application. Yet rather than signalling an inherent problem with the reach of these frameworks, the authors claim that the limitations are traceable to "the partial and incomplete way" in which US approaches "have been adapted for empirical work" (Harding et al., 2000, p. 987) or, in similar vein, to problems of "misclassification" and "concept stretching" (Mossberger and Stoker, 2001). Both reviews conclude by stressing the need for a more "careful", "rigorous" and "innovative" deployment of US concepts.

Drawing these conclusions effectively serves as a defence of the original regime and growth coalition frameworks in a context in which work on urban politics and governance is characterised by a growing diversity of theoretical and methodological approaches (for recent reviews, see MacLeod and Goodwin, 1999; and DiGaetano and Strom, 2003). This is especially true of work on Britain where, arguably, no single approach is now dominant, as advocates of regulation theory (Jones, 1997; MacLeod, 2001) jostle with more constructivist or agency-centred accounts focusing on the 'practice' and 'performance' of government (Raco and Imrie, 2000; McNeill, 2002; MacKinnon, 2000). Rational-choice accounts also continue to attract some attention (Dowding et al., 1995, 2000).

The context of an expanding array of approaches to urban politics provides an opportunity to reflect on the merits and limits of US frameworks and to assess the utility of regime and coalition concepts for cross-na- tional work. Whereas Harding et al. and Mossberger and Stoker argue that the potential of these frameworks remains largely untapped, this paper develops a contrary thesis that foregrounds more fundamental limitations. I review recent studies to suggest that the explanatory capacities of US frameworks, and thus their prospects, are decidedly limited (see also Dowding, 2001). In short, the paper argues that the problem of applying US frameworks is much more fundamental than one of poor 'translation'.

The paper focuses on Britain and specifically on the political mobilisation and engagement of business interests in British cities. There are three reasons for this. First, while US frameworks have now been applied to a wide range of different contexts, there is a particularly sizeable and well-developed literature on the British case. The volume of such work allows for a reasonable assessment of the limits of cross-national application. Secondly, the question of business engagement has been central to arguments concerning the contextual reach of US theory. For Mossberger and Stoker (2001) business involvement in urban governance represents one of the necessary or 'core criteria' in determining the suitability of the regime framework for cross-national application. ${ }^{1}$ Thirdly, proponents argue that the focus on business interests provides one of the key advantages of regime and growth coalition theories over alternative frameworks. Harding et al. argue, for example, that in a context of growing private sector involvement in British urban governance, US approaches provide

a compelling argument about the importance of business fortunes to public officials ... [and] a number of pointers as to which interests are involved in urban coalition-formation, why and with what effect (Harding et al., 2000, p. 991).

The remainder of the paper is presented in five sections. The next briefly traces the development of British applications and provides a summary review of arguments for and against the use of US frameworks. Those 
eschewing the growth coalition and regime frameworks tend to emphasise the 'gap' between US and British contexts. Those defending the efficacy of the models argue for a much more careful specification and application. Section 3 critically examines an alternative set of state-centred approaches to explaining the changing nature of British urban governance. Such approaches are designed to transcend the limitations of US theory but in doing so marginalise an important set of questions concerning the nature and extent of business engagement in urban politics. In section $4, \mathrm{I}$ take this issue further and review recent work that examines directly the nature and extent of business mobilisation at the urban scale. I argue that, despite the match between US urban theory and questions of business mobilisation and engagement, the propositions deriving from the US literature largely fail to hold up to empirical scrutiny. A fifth and final section uses this finding to draw four conclusions relating to the generalised use of US theories and makes a number of suggestions for how theorising and research might incorporate some of the virtues of urban regime and growth coalition models, while at the same time moving squarely beyond them.

\section{British Applications and the Value of US Theory}

The US-based literature on urban politics has clearly proved to be a popular and productive source for those seeking to examine the changing forms of politics and governance in Britain's cities. Before considering these applications, it is worth sketching out the basic tenets of the two major US approaches-the growth machine and the urban regime (extended reviews are provided by Stoker, 1995; Ward, 1996; and Harding, 1999). The growth machine concept dates to Harvey Molotch's seminal (1976) argument that US cities should be understood in terms of the efforts of property-owning élites to realise their interests in urban growth. Later extension of the argument (Logan and Molotch, 1987) sought further to specify growth interests and examine the ways in which these interests mobilised local governments in order to pursue growth strategies. Logan and Molotch argue that the effects of growth coalition activities work to reproduce and further existing social divisions within the American city.

The notion of the urban regime derives from the work of Clarence Stone and Stephen Elkin (Stone, 1989; Elkin, 1987). Both Stone and Elkin retain an emphasis on landed élites in understanding the politics of US cities, but broaden their analytical scope to examine the various governing arrangements through which political and economic interests seek to reproduce their power. In this sense, regime theory represents a broader framework that can be used to characterise variation between cities in the nature of their governing arrangements. Stone in particular has argued that interests, and the relationships between them, commonly crystallise into relatively stable configurations based upon a common understanding and agenda that reflect the goals of those that make up governing coalitions or regimes.

The earliest British applications of these ideas drew on the notion of the growth coalition as a way of framing a set of concrete changes that seemed to mark convergence between the British and US cases (Cooke, 1988; Lloyd and Newlands, 1988; Bassett, 1990; Bassett and Harloe, 1990; Harding, 1991; Axford and Pinch, 1994; Lawless, 1994). A second, and closely connected, set of studies shortly followed, drawing more heavily on the urban regime literature and Stone in particular (Harding, 1994; DiGaetano and Klemanski, 1993a, 1993b; Stewart, 1996; Boyle, 1993; Bassett, 1996). The majority of early accounts, whether adopting the growth coalition or urban regime model, focused on an individual British city or locality or, more occasionally, a handful of comparative cases within Britain (for reviews, see Ward, 1996; and Harding, 1999). ${ }^{2}$

In reviewing this literature, Harding (1999) and colleagues (Harding et al., 2000) identify three major and critical differences between British- and US-based work. The 
first is the general emphasis on public-sector agencies and local authorities in particular and, in turn, the limited recourse to examining the role and influence of private-sector interests on coalition building or local strategy. ${ }^{3}$ Secondly, those accounts that address the relationship between state and private interests are seen to focus firmly on formal or institutionalised forms of cross-sectoral collaboration, primarily in the guise of publicprivate partnerships or quangos. ${ }^{4} \mathrm{~A}$ third key difference between British and US work lies in establishing what properly constitutes an urban regime. Harding (1999) argues here that work on Britain tends to employ an overly elastic notion of a regime by dropping the requirements of longevity and robustness that are central to US work. This is a problem recognised by others (Dowding, 2001, p. 8). Mossberger and Stoker express similar concerns over the "misclassification" of urban regimes, arguing that

The problem is that all cities are assumed to be regimes... [but] whether a regime exists in a particular place is an empirical question (original emphasis) (Mossberger and Stoker, 2001, p. 815).

These differences in the focus of British- and US-based research clearly complicate attempts to assess the value of US theories and concepts in examining urban politics and governance in Britain. In asking whether or not US approaches 'work' in the British case, the existing literature provides two conventional answers.

1. Yes, providing the frameworks are carefully attuned to the British context.

2. No, given that contextual differences simply overwhelm their explanatory capacity.

In the first camp, Stoker and Mossberger (1994) argue that US-based theories work once 'cleansed' of their ethnocentric assumptions. More recently, the same authors have argued that recent cross-national research demonstrates

the utility of using the regime concept to explore the extent of business partici- pation, the motivation for business participation, and other differences as well (Mossberger and Stoker, 2001, pp. 824$825)$.

Those that eschew US frameworks do so on the basis that they remain heavily embedded in the specific circumstances of the US case. Peck and Tickell-for example, suggest that, "the growth machine hypothesis ... remains a framework with which to understand the particularity of US politics" (Peck and Tickell, 1995, p. 59; emphasis added). Bassett, although not explicitly rejecting regime theory, argues that the regime concept assumes horizontal linkages and coherence between interests, whereas in the UK vertical linkages within political hierarchies are much more important in determining local politics (Bassett, 1996, p. 550). In short, this set of arguments suggests that stripping these ideas of their 'ethnocentric assumptions' leaves little residual explanatory capacity. Both Dowding and Bassett revert to the alternative of political networks as a means of describing and analysing urban governance and its politics (Dowding, 2001; Bassett, 1996). Peck, Tickell and others following a similar line, plump instead for a variant of regulation theory attuned to the local specificities of political and economic activity.

It is clear then that commentators have drawn opposite conclusions concerning the significance of context in limiting the reach of urban regime and growth coalition theory. Mossberger and Stoker see significant potential given a careful 'tuning' of US theory, while Peck and Tickell see limited explanatory capacity beyond the country of origin. These contrary positions are difficult to resolve and their oppositional nature helps to account for the current impasse. Yet Harding's critical review of existing work raises a third, and intriguing, possibility in determining the value of US frameworks in the British case. Harding suggests that the limited returns to recent work are the consequence of the misapplication of US models; that is, the theories are poorly applied, focusing on the wrong sets of issues, phenomena 
and events. This argument holds out the possibility that the frameworks retain significant but presently untapped explanatory potential. In short a shift in research focus would generate significant returns to the application of US models.

In advancing this case, Harding cites the "abuse" of North American urban political economy, arguing that

much of the British research on urban regimes and growth machines adopts the language associated with the two approaches but fails to test many of its propositions in anything more than rudimentary fashion (Harding, 1999, p. 685).

The silences in the case of work in the growth coalition tradition include

little reference ... to the function of rentiers, the importance of 'place-boundedness' for business mobilization ... or the role of local capital in influencing the priorities of local authorities and the investment decisions of metropolitan capital (Harding, 1999, p. 683).

Additional problems with regime accounts include a neglect of both the informal processes through which influence and resources are exchanged as well as specification of the mechanisms that secure the reproduction of particular regimes. Harding also notes a general failure to incorporate the normative concerns of regime and growth coalition literatures in addressing the regressive nature of coalition-orchestrated urban development. In the next section, I argue that more recent work on Britain, drawing to a greater or lesser degree on the regime and growth coalition traditions, has sought to address precisely some of these 'missing links' (Ward, 2000; Rogerson and Boyle, 1998, 2000; Bassett, 1996, 1999; Bassett et al., 2002; Raco, 2003a, 2003b; Wood et al., 1998; Valler et al., 2000; North et al., 2001). The conclusions derived from this work regarding the utility of regime and growth coalition concepts are set out in the final section of the paper. Critical assessment of US frameworks has encouraged those studying British cities to turn to alternative accounts. The most influential in examining the increasing role of local business élites within urban politics is the state-centred approach advanced by Peck and Tickell. The next section explores this approach more fully. I argue that, despite significant theoretical advances in examining urban politics and governance in Britain, the approach neglects an important set of questions concerning the mobilisation and engagement of business interests. This is precisely the space that US frameworks promise to fill. I argue in section 4, however, that recent empirical studies highlight the limits of US frameworks and thus the need for a renewed phase of theory building.

\section{Centring the State}

Whether arguing for or against US theory, the principal cause of translation problems is seen to lie in the variability of state structures. Differences include the size, scope and political composition of the state, its autonomy from civil or private interests, and business interests in particular, and the territorial form of the British state. In crude terms, the British state and its local components is bigger, broader, more powerful, left-leaning, less porous to business interests and more centralised than its US counterpart (Ward, 1996; Cooke, 1988; Valler, 1996; Harding, 1999; Davies, 2003). While the process of governance rescaling continues to amplify the salience of the sub-national level in Britain, as well as elsewhere in Europe (Boyle, 2000; Brenner, 1999), significant differences in state form clearly help to account for the direction in which British work has taken US models.

Despite these differences, observers across the theoretical spectrum are widely agreed that, formally at least, businessmen and women and their representative organisations have a more prominent place in British urban politics than at any time since the Victorian era (Peck, 1995; Peck and Tickell, 1995). However, we should recognise that this enhanced participation has been generated from a relatively low base level through the 20th 
century. The combination of a more centralised state with a relatively weak tradition of political mobilisation of business interests at the local scale readily lends itself to a particular explanation of the growing formal engagement of business interests in urban governance and policy-making. In short, this development is seen to arise not from the relatively autonomous mobilisation of business interests, characteristic of the US case, but rather as part of a national-state project designed to restructure local government along neo-liberal lines. Businessmen and women serve as the advanced guard of a national ideological and political project and are "conscripted" and "drafted" in to "front" organisations and funding bids (Peck and Tickell, 1995, p. 55; Jones and Ward, 1998, p. 31; Ward, 2000, p. 1098 respectively; see also Davies, 2003).

In these accounts, business interests and organisations are positioned as a tool through which a particular political-economic agenda-the neo-liberal reform of the stateis implemented. Accordingly, many of those working on urban politics in Britain have looked to state theory as a means of providing the requisite leverage to explain a statedriven and orchestrated process of political mobilisation. Without wanting to deny the critical significance of state restructuring, I argue that such accounts fail to address three questions that are important in establishing a rounded account of urban and regional politics and governance and the important role of business interests and organisations within them. The first is why, in the absence of compulsion, do businessmen and women answer the "call to arms"? (Peck and Tickell, 1995 , p. 55). Peck hints at an answer in suggesting that the business people "selected" in by the state tend to be of a different type from those traditionally active in representing business interests

It was the maverick entrepreneur, rather than the bureaucratic manager, who came to form the 'new' business élite under Thatcherism (Peck, 1995, p. 24; see also Rogerson and Boyle, 1998).
Participation is thereby rooted in a shared ideological zeal on the part of individual businessmen and women. There is little further assessment of the mechanisms driving engagement or the incentives that structure its form. On this matter, the contrast with the US literature is particularly stark; growth coalition and regime formulations and the critical extension of this work by others, such as Cox and Mair, all focus centrally on the various material interests that underpin business politics (Cox and Mair, 1988, 1989). British work in the state-centric tradition lacks a similar specification of business interests. It is clearly difficult to test US theory in the absence of this.

Secondly, the mechanisms through which the central state choreographs an 'appropriate' role for business interests in furthering its neo-liberal project are not entirely clear. While a political stage for business is created via rules concerning the composition and operation of new governing institutions, this is sufficient neither to ensure business participation (see above) nor to manipulate the players such that they behave according to script. In short, empowering newly mobilised business élites is by no means sufficient to guarantee that they will deploy their newfound powers in the ways intended. Business interests remain relatively autonomous from the political interests that seek to orchestrate their engagement. The granting of greater discretionary power to the business-led Training and Enterprise Councils (TECs) and greater budgetary resources and flexibility to the Regional Development Agencies (RDAs) hints at some of the problems of seeking to exercise control at a distance (Jones, 2001). In both cases, central government has had to satisfy demands for greater resources and power made by these 'business-led' institutions.

The slippage between the scripted role for business interests and their actual performance appears to be considerable. Furthermore, a dynamic is now in play that has seemingly encouraged further and continuing demands on the part of business interests and organisations for greater resources on the one 
hand and enhanced discretionary authority over their use on the other. ${ }^{5}$ Bassett's work on Bristol indicates that, while state sponsorship of an enhanced business role may have been a critical initial stimulus to business mobilisation, more recent developments from within the business community have created a "much more organised and also more influential" set of interests (Bassett, 1999, p. 188). Raco similarly argues that the devolution of political power to Scotland has

enhanced the politicisation of some sections of the business community in a number of ways. Voluntary membership has increased for all the organisations ... This has reflected both the growing demand amongst the business community for membership of representative organisations and an enhanced awareness amongst such groups of the importance of developing a strong membership base in the context of political arrangements (Raco, 2003a, p. 85).

These cases clearly point to the potential for significant slippage between the political rationale for and the routine practice of business engagement in new forms of urban and regional governance.

Thirdly, state-centred explanations commonly fail to specify the manner in which and the extent to which business interests modify governance structures and facilitate the shift towards a neo-liberal agenda (Harding et al., 2000). The greater formal presence of business interests in the political and policy-making arena should not be automatically seen as an accurate measure of their strength or capacity to effect change (Harding et al., 2000, p. 982; although see Peck and Tickell, 1995, p. 58). Bassett et al.'s (2002) more recent work on Bristol demonstrates the inability of business interests and organisations, in alliance with local political élites, to force through urban development projects. In the absence of detailed empirical work on the impact of business engagement, recent attempts to evaluate change have had some difficulty in assessing how "local business leaders enforce the new regulatory rules 'on the ground'" (Peck and Tickell, 1995, p. 62, see also Valler et al., 2000).

These three issues suggest that accounts of business engagement centring on the restructuring of the state are partial in what they seek to explain and, in turn, how explanations are constructed. While they may be able to account for the formal involvement of business interests on visible and high-profile boards and organisations, such as the RDAs in England, they are much less adept at explaining the broader process of business mobilisation at sub-national scales, a process which can occur at some remove from the state or even quasi-state 'partnership' bodies. As previously argued

Explicit attempts to problematise the form and character of private sector representation have been only limited and partial. The nature of local business interests, their translation into and through specific discourses and institutional forms, and the motivations underlying particular patterns of business representation, remain largely neglected (Wood et al., 1998, pp.11-12).

Rather than focusing singularly on formal partnerships and committees and the 'selecting in' of certain interests in the manner favoured by state-centric accounts, a number of recent studies have begun to develop a complementary consideration of the factors that tend to drive business engagement. With a focus on the composition of business interests, the tactics and strategies through which business agendas are constructed and the effects of their deployment, this work largely avoids the problem of 'misapplication'. In contrast to state-centred approaches, this work provides a much more accurate gauge with which to measure the merits and limits of US frameworks in the British context.

\section{Beyond the State}

Rather than starting out with the restructuring of state forms, and the role of business interests within this process, a number of recent studies have sought to examine much more directly the differential mobilisation of 
business interests and the processes through which business interests and agendas are constructed and deployed (Rogerson and Boyle, 1998, 2000; Raco, 2003a, 2003b; Wood et al., 1998; North et al., 2001). In order to assess the efficacy of US theories in explaining these patterns of business mobilisation and engagement, I set out the claims arising from the US literature on, first, the composition of local business interests and, secondly, the expected relationship between interests and political mobilisation. I then briefly review a number of recent studies to assess the extent to which results match these claims. This is followed by a discussion of work by the author (and colleagues) on local business mobilisation in economically disadvantaged industrial towns in the North and Midlands of England, which has been explicitly concerned with the mechanisms that generate political activity on the part of business interests (Wood et al., 1998; Valler et al., 2000; North et al., 2001).

On the question of the composition of growth coalitions and urban regimes US theories provide a very clear guide as to "which interests are involved in urban coalition formation, why and with what effects' (Harding et al., 2000, p. 991). Central to growth coalitions are what Logan and Molotch variously term "rentiers", place entrepreneurs or "parochial capital" (Molotch, 1976; Logan and Molotch, 1987). Place entrepreneurs are defined as "the people directly involved in the exchange of places and collection of rents" (Logan and Molotch, 1987, p. 29) and principal among them are individuals directly connected to real estate and real estate development. Beyond the rentier core lie a host of other growth machine participants including local politicians, the local media and the utilities, as well as a further set of "auxiliary players" that have a somewhat more tangential relationship to growth (Logan and Molotch, 1987, pp. 62-85). As noted above, the mobilisation of local governmental power and authority enables business interests to realise economic gains through the intensification of land use and the coincident growth of economic activity.

Regime theory is rather more catholic in its specification of the interests that underpin governing regimes. While 'landed interests' are highlighted, regime theory's concern with variation between cities allows for a broader typology of different governing forms and agendas as well as the range of business interests that underpin them. In critically extending these arguments, Cox and Mair similarly insist that the material attachments that drive business involvement extend beyond interests in land. They suggest a range of additional forms of fixity that generate a 'local dependence' on the fortunes of a specific or particular geographical locale (Cox and Mair, 1988, 1989). Accordingly, we would anticipate that the business interests active in British urban politics would exhibit 'local dependence' of some form.

On the question of the relationship between interests and mobilisation, US theory indicates that locally dependent interests are liable to take an active role in local politics as a result of a significant material stake in the local economy on the one hand, and the prohibitive costs of exit from the locality on the other. However, the relationship between local dependence and political engagement reflects a tendency rather than an empirical regularity (Cox, 1998). Empirical work must, therefore, recognise various possible combinations of local dependence and political engagement on the ground (Table 1).

Table 1. The dependence-engagement relationship

High local dependence
Low local dependence 
The four possible combinations, whether at the level of the individual business or the local business community more broadly, include a direct and positive relationship between levels of dependence and the extent of engagement (quadrants 1 and 4 in Table 1). ${ }^{6}$ Coalition and regime literatures indicate that, on a comparative cross-national basis, business politics in US cities tends to fall squarely in the top-left quadrant. Indeed, critics argue that US-based accounts have developed to address precisely this set of conditions in which a clearly specified set of local material interests engage in collective political activity in order to promote and structure local economic development.

However, there are two interesting alternative scenarios that represent a disjuncture between interests and engagement at the local scale. In the case of quadrant 3, high levels of local dependence may translate into only limited or partial political expression of those interests at the local scale. Pincetl outlines just such a case in Orange County, California, involving a channel of influence on the part of a major property developer that extends directly to the federal level (Pincetl, 1999). Cox (1998) also provides a number of examples of the ways in which agents and organisations can 'jump' scales in giving political expression to their locally dependent interests. There is, therefore, no necessary reason why the spatial scale of interests should equate to that of their political expression. In the case of British cities, we need to be open to the fact that local business interests might be given political expression at regional, national or even international scales (such as via the European Union) rather than, or more likely in addition to, their articulation at the local level.

The fourth possibility (quadrant 2) represents one of an engaged business population but on the basis of relatively low levels of local dependence. This would record as a US-type scenario in terms of the empirical extent and configuration of business mobilisation, albeit in the absence of the same generating mechanisms. In short, a similar set of empirical outcomes are produced by an es- sentially different set of causal mechanisms or processes. ${ }^{7}$

The empirical findings from three recent British studies that address, at least in part, the dependence-engagement relationship can be interpreted through the lens of Table 1. The studies are Bassett's work on Bristol, Ward's study of Manchester and Rogerson and Boyle's study of business politics in Glasgow. None of these studies records a US quadrant-1-type condition, which must then bring into question the utility of US frameworks in accounting for the observed patterns. In the case of Bristol, Bassett's examination of the new business élite found that "although most of their firms stood to gain indirectly from renewed local growth, there was little evidence of direct benefit from involvement in partnership activities" (Bassett, 1999, p. 187). Motivations for participation were rooted in a range of concerns including a reaction to "local complacency and lack of leadership" (p. 187) as well as "the social responsibilities of business leaders to put something back into their communities" (Bassett, 1999, p. 187). In this case, relatively high levels of engagement are produced through mechanisms other than the local dependence of interests (quadrant 2).

Ward's (2000, 2004) work on Manchester suggests a closer approximation to conventional growth coalition and regime formulations in demonstrating how a group of "property-owning entrepreneurs" (2000, p. 1103) sought to mobilise local political actors and resources in seeking to "safeguard" economic assets and "increase the value of their land and property" (Ward, 2000, p. 1099). While Ward's findings suggest a quadrant-1-type scenario, this collection of economic interests lacked the coherence and longevity deemed essential to regime or growth coalition definition. Indeed, having achieved its specific goal of reconfiguring the nature of Manchester's marketing initiatives, the group quickly disbanded, retreating to a quadrant-3-type condition.

Rogerson and Boyle's (1998, 2000) study of business politics in Glasgow references a 
similar mobilisation of property interests but again finds that commitment to political activity remains limited and restrained. They argue that in the case of the Glasgow Operatives Club, a partnership organisation dedicated to attracting inward investment into Glasgow, business involvement "is piecemeal, project based and for the most part reactive" (Rogerson and Boyle, 1998, p. 116). Furthermore, their overall assessment points to the absence of a "highly motivated local business class, keen to articulate a coherent political voice. Involvement has perhaps not been lethargic, but neither has it been enthusiastic" (p. 116). In one of the rare attempts to specify concretely the local dependence of business interests, Rogerson and Boyle conclude that, "the Glasgow Operatives Club consists of firms who are not, in the main, locally dependent upon the Glasgow economy" (1998, p. 118). Their findings reference a quadrant-4-type scenario but with sporadic political activity that points in the direction of quadrant 2. Recent research in Bristol, Manchester and Glasgow has failed to find a politically coherent coalition-like set of business interests with strong material ties to the urban economy. Yet in each case, business mobilisation has tended to increase over time through the formation of new partnership-type organisations, the increased activities of traditional business organisations, like chambers of commerce and the more sporadic political activities described by Ward in the case of Manchester.

Work by the author and colleagues on three economically disadvantaged industrial towns in the North and Midlands of England, has also sought to describe and explain these emerging patterns of business mobilisation. The research focuses on three broad issues: first, the relationship between interests, identities and the politicisation of business; secondly, on the construction of business agendas; and, thirdly, on the relationship between business interests and economic development strategies. The project involved semi-structured interviews with 34 business men and women, and a further 20 interviews with representatives of business organisa- tions, partnerships and local and central government. The interviews explored a number of questions focusing on how business men and women interpreted their involvement in local political affairs, how business identities and agendas were constructed and mobilised and how effective these strategies have been in producing change. The interviews also sought to specify the nature and extent of commitments to the local economy in the form of the fixity of assets, dependence upon local supply and customer networks, labour skills or immobility in the form of a strongly localised brand or reputation. In short, the research sought to specify the level, nature and spatial extent of local dependence and match this to the degree and nature of political involvement.

US frameworks predict a clear relationship between interests, identities and collective political action on the part of business actors-a quadrant-1-type condition. Yet detailed analysis of the interview transcripts failed to find any simple logic of business mobilisation rooted in local material interests, whether in terms of fixed assets or some other dimension of local dependence. Indeed, the ties between firm characteristics and the extent and nature of their political activity were complex and variable. For the most part, the motivations driving engagement were not readily reducible to any simple set of commercial dependencies on the locality. Here, the findings parallel the work on Bristol, where business leaders "did not seem to be narrowly motivated by economic gain" (Bassett, 1996, p. 547), as well as the previously referenced work on Glasgow (Rogerson and Boyle, 1998).

This is not to argue that there was no evidence at all of material stakes driving political activity. Indeed, an instrumental economic rationale was evident in accounting for involvement in a number of cases. Yet many business men and women interpreted their actions in terms of a strong cultural attachment or affinity for the local area. One particularly active retired business executive emphasised his local roots, "If you were to cut me in half, you'd find Barnsley 
written inside me". A second local retailer explained his family firm's involvement in local business politics in similar, albeit less colourful, terms

We are concerned with the town. I mean we've lived here, we've never lived anywhere else-Accrington is our life-we would like it to be much better than it is so we are concerned for it.

Other individuals tended to frame their involvement in terms of a positive individual or corporate commitment to social responsibility

I'm somebody who enjoys life a great deal and I think that if you're fairly fortunate in life you ought to be prepared to get off your backside and put a bit back into it - and that's broadly me-it's a very simple philosophy but that's broadly it, you've got to get off your backside and put something back in.

Another businessman expressed his reasons for participation in local political activities as "an obligation, a feeling of obligation to get involved with the area in some way ... we are such a big employer in the area we needed to put something back". The careful and detailed analysis of transcripts revealed a diverse set of relationships between individual, corporate and professional logics of political engagement that more often than not belied a US model in which individual and collective action is generated through an instrumental relationship to local economic fortunes.

On the question of economic development agendas and strategies, Logan and Molotch posit a collective interest in 'growth' as the ideological glue sustaining coalitional forms. Regime accounts encompass a broader range of objectives and strategies but still posit a relatively straightforward relationship between interests and agendas. In the case of the three English towns, the research failed to find any such simple relationship between business interests, identities and support for a particular model of local economic development. Indeed, analysis of transcript materials indicates that support for economic development among business interests in each of three study localities was far from universal, with a number of firms clearly locked into a corporate strategy that rested firmly upon the depressed nature of the local labour market. For a significant number of employers, high unemployment and the ready availability of unskilled and semi-skilled labour proved a blessing rather than a curse. A manager at a large manufacturing firm noted that local recessionary conditions "would probably help us ... because it would make labour more readily available". Other firms were wary of a growth strategy tied to attracting significant inward investment for fear of rising wage costs and the poaching of labour (Wood et al., 1998). While business interests claimed a significant role in generating local wealth and providing employment opportunities, there was little agreement as to the nature of the problems facing the locality, the appropriate strategy for addressing economic decline and thus no reasoned and consistent business agenda to provide the basis for a coherent and robust local coalition or urban regime. While each of the three localities has seen an increase in the level of business mobilisation and engagement over the past decade, it would be impossible to classify this as the development of coalition or regime-like forms. Instead, business interests are differentially connected to the local economy, fractured around basic questions of economic strategy and generally reactive to political issues and policy.

\section{Conclusions}

This review of the literature and findings from recent studies raises four issues concerning the generalised use of US theories in analysing urban politics and governance in Britain. In this concluding section, I want to discuss these issues and then address how theory building might develop beyond the limits of regime and growth coalition accounts. First, and perhaps most obviously, they suggest that the capacity of US frameworks to explain patterns of business mobil- 
isation is limited. This observation applies across the range, including the notion of 'local dependence' as well as the more widely used growth coalition and urban regime concepts. The specification of the local dependence of economic actors fails to generate the range of politically mobilised business interests anticipated by US accounts. Neither can the pattern of politically active business interests be readily tracked back, or reduced, to material stakes at the local scale. Whether one moves from interests to political practice or from practice to interests, the analysis of business mobilisation in Britain points to a range of mechanisms and motivations beyond those identified by US frameworks; a 'core interest' or dominant 'logic of engagement' along US lines proves elusive.

Secondly, the findings render problematic recent reviews of British applications of US theory, notably those of Harding (1999) and colleagues (Harding et al., 2000) and Mossberger and Stoker (2001). For even when properly targeted on the 'appropriate' objects of study, the findings fail to support the principal claims derived from US work. In avoiding the problem of misapplication, recent work suggests that the shortcomings of US frameworks are founded either in the gap between the US and British contexts or, even more troublingly for US theories, in structural problems inherent to those frameworks.

The third issue follows from the previous observation. In the absence of a significant body of systematic comparative cross-national research, it is difficult to assess properly the extent to which the limits identified in the work on Britain resonate more widely. At minimum, we should recognise that the problems of translation provide an opportunity for a critical assessment of the dominant frameworks for interpreting and understanding US urban politics. If limitations of contextual reach illuminate certain shortcomings in US-based theories, then it behoves us to ask whether and to what extent these deficiencies might also apply at home? One such question is to what extent business engagement in the US case is also driven by logics beyond those of an instrumental material nature (Austin and McCaffrey, 2002).

Fourthly, the findings might well be interpreted as confirmation of state-centred readings of mobilisation in the British case. The paucity of direct material incentives suggests that the key to mobilisation may well rest instead in the missionary zeal that leads individual business men and women to answer the state's call to restructure local institutions of government. Yet, as indicated in section 3, the scale, extent and complexity of mobilisation indicate the partial nature of this view. Furthermore, reasons for participation are found to be complex, variable and irreducible to a single logic. While for the most part explanation of the patterns fails to reduce to a local economic embeddedness on the part of individual firms, neither is it singularly located, as state-centred work suggests, in a desire to enfeeble or eviscerate elected local authorities.

In the late 1980s, academics studying Britain's cities began to embrace the US concepts of the growth coalition and the urban regime. Alternative frameworks at that time were decidedly limited in addressing a range of concrete changes that seemed to mark convergence with the US context. A decade or more later those interested in urban politics and governance are confronted with a veritable array of different frameworks. These include, but are by no means limited to, variants of regulation theory (Lauria, 1997; Peck and Tickell, 1992; Jessop et al., 1999), actor and policy networks (Bassett, 1999; McGuirk, 2000; Lowndes et al., 1997), discourse analysis (Imrie et al., 1996; and the papers in Urban Studies, January 1999), Foucauldian theories (Raco, 2003a; Raco and Imrie, 2000; MacKinnon, 2000), rational choice (Dowding, 2001; Dowding et al., 2000) and accounts rooted in the social movement literature (North et al., 2001). This wealth of new approaches holds much promise for future work on theorising urban politics and governance.

Yet displacing regime and growth coalition models will be no simple matter. Their attractiveness derives in large part 
from their grounding in a political-economy tradition, while retaining an appreciation for the dynamic complexity and variability of urban politics. Current alternatives commonly fail to harness the structure-agency dynamic in the same way, tending towards one pole or another in seeking to understand the nature of urban politics and governance. Accounts rooted in actor and policy networks, as well as the social movements literature, emphasise the dynamics of political action. In examining the political mobilisation of business interests, such accounts have been helpful in determining the ways in which business identities and agendas are constructed and deployed. Yet such accounts commonly tend to bracket out broader changes in the economic and political conditions within which individuals and institutions collaborate and act. Structural change in the nature of the state and state forms provides the most obvious example. Accounts rooted in regulation theory, or other variants of neo-Marxist state theory, squarely address this particular issue. But, as evidenced in section 3 , such accounts tend to explain changes in the nature of business mobilisation and engagement through the singular lens of state restructuring and the role of business interests within that process.

An alternative that seeks explicitly to transcend the structure-agency dualism is Hay and Jessop's strategic-relational approach (Hay and Jessop, 1995; Jessop, 2001; and Hay and Richards, 2000). Although there is space here to provide no more than a skeletal account, the strategic-relational approach promises to transcend many of the limitations of the urban regime and growth coalition models, while retaining an emphasis on political dynamics within a changing structural context. At its most basic level the strategic-relational approach encourages a focus on strategic calculation and actions and the ability of individual and collective actors to learn and adapt. The emergence of a more 'politically savvy' set of local business interests in Britain is suggestive of such a process and indicates that they operate in a relatively autonomous fashion from any ascribed struc- tural 'logic' (Valler and Wood, 2004). Yet at the same time, the strategic-relational approach emphasises that the context for action is 'strategically selective' in privileging certain interests and activities. The process of state restructuring in Britain and its clear tendency to 'select in' business interests and organisations differentially, in preference to other actors and social groups is suggestive of this dynamic.

Clearly, much work remains in developing the strategic-relational approach, not least in demonstrating the efficacy of such a framework for empirical research. Yet arguably the approach provides a means of harnessing the diversity of current approaches, retaining an emphasis on the dynamics of strategic action and, at the same time, recognising the strategically selective nature of the context within which that dynamic unfolds. The argument set out in this paper suggests that it may well be time to embrace and develop such an alternative, acknowledge the considerable debt to traditional US theories and move squarely beyond them.

\section{Notes}

1. "There are ... fundamental reasons for having business participation at some level as a necessary ingredient for urban regimes" (Mossberger and Stoker, 2001, p. 825).

2. The one notable exception here was DiGaetano and Klemanski's cross-national work on Birmingham and Detroit (DiGaetano and Klemanski, 1993a, 1993b, see also DiGaetano and Lawless, 1999, on Birmingham, Sheffield and Detroit).

3. Examples cited here include the early work of Bassett (1990) and Bassett and Harloe (1990) on Swindon, and the more recent work of Dowding and colleagues (1999) on London.

4. Cited work here includes Ward (1996), Lloyd and Newlands (1988) study of Aberdeen and Axford and Pinch's (1994) analysis of the Hampshire Development Authority. Davies (2003) has a similar emphasis.

5. The recent Confederation of British Industry review RDAs: Getting Down to Business established a 10-point action plan that included a demand for greater "budgetary flexibility and operational freedom" coupled with 
"stronger engagement with business" and the need for an even more substantial business presence on RDA Boards (CBI, 2001).

6. Individual firms can be positioned within the table, as can local business communities as a whole. However, the latter exercise must be undertaken with caution given significant variations between firms in the nature, level and spatial extent of their local dependence.

7. A number of British studies in the regime mould devote considerable energy to the construction of regime typologies based on concrete characteristics of governing coalitions. Yet as Ward suggests

It is the mechanisms underpinning the forming of regimes rather than superficially similar concrete outcomes which will provide urban regime analysis with theoretical power (Ward, 1996, p. 429).

\section{References}

Austin, J. and McCAffrey, A. (2002) Business leadership coalitions and public private partnerships in American cities: a business perspective on regime theory, Journal of Urban Affairs, 24, pp. 35-54.

AXFORD, N. and PINCH, S. (1994) Growth coalitions and local economic development strategy in southern England, Political Geography, 13, pp. 344-360.

BASSETT, K. (1990) Labour in the Sunbelt: the politics of local economic development strategy in an "M4-Corridor" town, Political Geography Quarterly, 9, pp. 67-83.

BASSETT, K. (1996) Partnerships, business élites and urban politics: new forms of governance in an English city?, Urban Studies, 33, pp. 539555.

BASSETT, K. (1999) Growth coalitions in Britain's waning Sunbelt: some reflections, in: A. JONAS and D. WILSON (Eds) The Urban Growth Machine, pp. 177-193. Albany, NY: State University of New York Press.

Bassett, K. and Harloe, M. (1990) Swindon: the rise and decline of a growth coalition, in: $\mathrm{M}$. Harloe, C. Pickvance and J. Urry (Eds) Place, Policy and Politics, pp. 42-61. London: Unwin Hyman.

BASSETt, K., GRIFFITHS, R. and SMITH, I. (2002) Testing governance: partnerships, planning and conflict in waterfront regeneration, Urban Studies, 39, pp. 1757-1775.

Boyle, M. (2000) Euro-regionalism and struggles over the scales of governance: the politics of Ireland's regionalisation approach to Structural Fund allocations 2000-2006, Political Geography, 19, pp. 737-769.

BOYLE, R. (1993) Changing partners: the experi- ence of urban economic policy in west central Scotland, 1980-90, Urban Studies, 30, pp. 309-323.

BRENNER, N. (1999) Globalisation as reterritorialisation: the re-scaling of urban governance in the European Union, Urban Studies, 36, pp. 431-451.

CBI (CONFEDERATION OF BRITISH INDUSTRY) (2001) RDAs: Getting Down to Business. London: CBI.

COOKe, P. (1988) Municipal enterprise, growth coalitions and social justice, Local Economy, 3, pp. 1319-1336.

Cox, K. (1998) Spaces of dependence, spaces of engagement and the politics of scale, or: looking for local politics, Political Geography, 17, pp. 1-23.

Cox, K. and MAIR, A. (1988) Locality and community in the politics of local economic development, Annals of the Association of American Geographers, 78, pp. 307-325.

Cox, K. and MAIR, A. (1989) Urban growth machines and the politics of local economic development, International Journal of Urban and Regional Research, 13, pp. 137-146.

DAviES, J. (2003) Partnerships versus regimes: why regime theory cannot explain urban Coalitions in the UK, Journal of Urban Affairs, 25, pp. 253-269.

DiGaetano, A. and Klemanski, J. (1993a) Urban regime capacity: a comparison of Birmingham, England and Detroit, Michigan, Journal of $U r$ ban Affairs, 13, pp. 367-384.

DiGaetano, A. and Klemanski, J. (1993b) Urban regimes in comparative perspective: the politics of urban development in Britain, Urban Affairs Quarterly, 29, pp. 54-83.

DiGaetano, A. and Lawless, P. (1999) Urban governance and industrial decline-governing structures and policy agendas in Birmingham and Sheffield, England, and Detroit, Michigan, 1980-1997, Urban Affairs Review, 34, pp. 546-577.

DiGaetano, A. and Strom, E. (2003) Comparative urban governance: an integrated approach, Urban Affairs Review, 38, pp. 356-395.

DowDING, K. (2001) Explaining urban regimes, International Journal of Urban and Regional Research, 25, pp. 7-19.

Dowding, K., Dunleavy, P., King, D. ET $A L$. (1995) Rational choice and community power structures, Political Studies, 43, pp. 265-277.

Dowding, K., Dunleavy, P., King, D. et al. (1999) Regime politics in London local government, Urban Affairs Review, 34, pp. 515-545.

Dowding, K., Dunleavy, P., King, D. ET AL. (2000) Understanding urban governance: the contribution of rational choice, in: G. STOKER (Ed.) The New Politics of British Governance, pp. 91-116. Basingstoke: Macmillan Press. 
Elkin, S. (1987) City and Regime in the American Republic. Chicago, IL: University of Chicago Press.

Harding, A. (1991) The rise of urban growth coalitions, UK-style?, Environment and Planning $C$, 9, pp. 295-317.

HARDING, A. (1994) Urban regimes and growth machines: towards a cross-national research agenda, Urban Affairs Quarterly, 29, pp. 356382.

HARDING, A. (1999) North American urban political economy, urban theory and British research, British Journal of Political Science, 29, pp. 673-698.

Harding, A., Wilks-Heeg, S. and Hutchins, M. (2000) Business, governance and the business of urban governance, Urban Studies, 37, pp. 975-994.

HAY, C. and JESSOP, B. (1995) The governance of local economic development and the development of local economic governance: a strategic relational approach. Paper presented to the Annual Meeting of the American Political Science Association, Chicago.

HAY, C. and Richards, D. (2000) The tangled webs of Westminster and Whitehall: the discourse, strategy and practice of networking within the British core executive, Public Administration, 78, pp. 1-28.

ImRIE, R., PINCH, S. and Boyle, M. (1996) Identities, citizenship and power in the cities, Urban Studies, 33, pp. 1255-1262.

JESSOP, B. (2001) Institutional (re)turns and the strategic-relational approach, Environment and Planning A, 33, pp. 1213-1235.

Jessop, B., Peck, J. and Tickell, A. (1999) Retooling the machine: economic crisis, state restructuring and urban politics, in: A. JoNAS and D. WILSON (Eds) The Urban Growth Machine, pp. 141-159. Albany, NY: State University of New York Press.

JoNES, M. (1997) Spatial selectivity of the state? The regulationist enigma and local struggles over economic governance, Environment and Planning A, 29, pp. 831-864.

JoNES, M. (2001) The rise of the regional state in economic governance: 'partnerships for prosperity' or new scales of state power, Environment and Planning A, 33, pp. 1185-1211.

JONES, M. and WARD, K. (1998) Grabbing grants? The role of coalitions in urban economic development, Local Economy, 13, pp. 28-38.

LAURIA, M. (Ed.) (1997) Reconstructing Urban Regime Theory. Thousand Oaks, CA: Sage.

LAWLESS, P. (1994) Partnerships in urban regeneration in the UK: the Sheffield Central Area Study, Urban Studies, 31, pp. 1303-1324.

Lloyd, G. and Newlands, D. (1988) The 'growth coalition' and urban economic development, Local Economy, 3, pp. 31-39.
Logan, J. and Molotch, H. (1987) Urban Fortunes: The Political Economy of Place. Berkeley, CA: University of California Press.

Lowndes, V., NAnton, P., McCABE, A. and SKELCHER, C. (1997) Networks, partnership and urban regeneration, Local Economy, 11, pp. 333-342.

MacKinnon, D. (2000) Managerialism, governmentality and the state: a neo-Foucauldian approach to local economic governance, Political Geography, 19, pp. 293-314.

MACLEOD, G. (2001) Beyond soft institutionalism: accumulation, regulation and their geographical fixes, Environment and Planning A, 33, pp. 1145-1167.

MacLeod, G. and Goodwin, M. (1999) Space, scale and state strategy: rethinking urban and regional governance, Progress in Human Geography, 23, pp. 503-527.

McGuirk, P. (2000) Power and policy networks in urban governance: local government and property-led regeneration in Dublin, Urban Studies, 37, pp. 651-672.

MCNEILL, D. (2002) Embodying a Europe of the cities: geographies of mayoral leadership, Area, 33, pp. 353-359.

Molotch, H. (1976) The city as a growth machine: toward a political economy of place, American Journal of Sociology, 82, pp. 309332.

Mossberger, K. and Stoker, G. (2001) The evolution of urban regime theory: the challenge of conceptualization, Urban Affairs Review, 36, pp. 810-835.

North, P., Valler, D. and Wood, A. (2001) Talking business: an actor-centred analysis of business agendas for local economic development, International Journal of Urban and Regional Research, 25, pp. 830-846.

PECK, J. (1995) Moving and shaking: business elites, state localism and urban privatism, Progress in Human Geography, 19, pp. 16-46.

Peck, J. and Tickell, A. (1992) Local modes of social regulation? Regulation theory, Thatcherism and uneven development, Geoforum, 23, pp. 347-363.

PeCK, J. and TiCKell, A. (1995) Business goes local: dissecting the 'business agenda' in Manchester, International Journal of Urban and Regional Research, 19, pp. 55-78.

PINCETL, S. (1999) The politics of influence: democracy and the growth machine in Orange County, US, in: A. JONAS and D. WILSON (Eds) The Urban Growth Machine, pp. 195211. Albany, NY: State University of New York Press.

RACO, M. (2003a) Governmentality, subjectbuilding, and the discourses and practices of devolution in the UK, Transactions of the Institute of British Geographers, 28, pp. 75-95. 
RAco, M. (2003b) The social relations of business representation and devolved governance in the United Kingdom, Environment and Planning A, 35, pp. 1853-1876.

RACO, M. and IMRIE, R. (2000) Governmentality and rights and responsibilities in urban policy, Environment and Planning A, 32, pp. 21872204.

Rogerson, R. and Boyle, M. (1998) Glasgow's reluctant mavericks and inward investment strategy: local dependence and its applications, Scottish Geographical Magazine, 114, pp. 109119.

Rogerson, R. and Boyle, M. (2000) Property, politics and the neo-liberal revolution in urban Scotland, Progress in Planning, 54, pp. 133196.

Stewart, M. (1996) Too little, too late: the politics of local complacency, Journal of Urban Affairs, 18, pp. 119-137.

STOKER, G. (1995) Regime theory and urban politics, in: D. Judge, G. STOKER and H. Wolman (Eds) Theories of Urban Politics, pp. 54-71. London: Sage.

Stoker, G. and Mossberger, K. (1994) Urban regime theory in comparative perspective, Environment and Planning C, 12, pp. 195-212.

Stone, C. (1989) Regime Politics: Governing Atlanta, 1946-1988. Lawrence, KA: University Press of Kansas.

Urban Studies (1999) Special Issue: Discourse and Urban Change, 36(1).
VALLER, D. (1996) Locality, local economic strategy and private sector involvement: case studies in Norwich and Cardiff, Political Geography, 15, pp. 383-403.

VALLER, D. and WoOD, A. (2004) Devolution and the politics of business representation: a strategic-relational approach, Environment and Planning A, 24 (in press).

Valler, D., Wood, A. and North, P. (2000) Local governance and local business interests: a critical review, Progress in Human Geography, 24, pp. 409-428.

WARD, K. (1996) Rereading urban regime theory: a sympathetic critique, Geoforum, 27, pp. 427438.

WARD, K. (2000) From rentiers to 'rantiers': 'active entrepreneurs', 'structural speculators' and the politics of marketing the city, Urban Studies, 37, pp. 1093-1107.

WARD, K. (2004) Challenging the machine from within: urban entrepreneurialism and representations of the city, in: A. WOOD and D. VALLER (Eds) Governing Local and Regional Economies, pp. 277-300. Aldershot: Ashgate.

Wood, A. (1996) Analysing the politics of local economic development: making sense of crossnational convergence, Urban Studies, 33, pp. 1281-1295.

WoOd, A., Valler, D. and North, P. (1998) Local business representation and the private sector role in local economic policy in Britain, Local Economy, 13, pp. 10-27. 